\title{
Length-Weight Relationship and Condition Factor of Two Species of Tilapia and One Species of Mormyrops from a Tropical Dam in a Southwestern State, Nigeria
}

\author{
Omotayo $\mathrm{F}^{1 *}$, Oluwadare $\mathrm{A}^{2}$ and Modupe $\mathrm{AM}^{1}$ \\ ${ }^{1}$ Department of Zoology and Environmental Biology, Faculty of Science, Ekiti State \\ University, Nigeria \\ ${ }^{2}$ Department of Statistics, Faculty of Science, Ekiti State University, Nigeria
}

Research Article

Volume 2 Issue 2

Received Date: March 24, 2018

Published Date: March 31, 2018

DOI: $10.23880 /$ jenr-16000124

*Corresponding author: Fagbuaro Omotayo, Department of Zoology and Environmental Biology, Faculty of Science, Ekiti State University, Pmb 5363, Ado- Ekiti, Nigeria, Tel: +234 803492 5363; E-mail: omofagbuaro@yahoo.com

\section{Abstract}

The length-weight relationship and condition factor of Tilapia zillii, Oreochromis niloticus and Mormyrops anguilodes from Itapaji dam, Ekiti State Nigeria were examined in this study. A total of 150 Cichlidae which made up of 130 T. zillii (65 females and 48 males) and twenty-four O.niloticus (11females and 13 males) and 13 M. anguilodes (11 females and 2 males) procured directly from the Fishermen were examined for this research. The parameters ' $a$ ' and ' $b$ ' were determined from the linear regression of the log of length and weight of the fish when transformed into the growth equation, $\mathrm{W}=\mathrm{aL}^{\mathrm{b}}$. The values of ' $\mathrm{b}$ ' for the fish species ranged from -1.16 to 10.12 and the result showed that Cichlidae had negative allometric growth while the Mormyrops showed positive allometric growth. The condition factor ' $K$ ' value for females and males of O.niloticus were closer to the recommended range of 2.9 to 4.8 reported as suitable for matured freshwater species in the tropics while the ' $\mathrm{K}$ ' value of other two species were greater than 1 except in the female $M$. anguilodes. The difference in the ' $\mathrm{K}$ ' values may be caused by the variation in weight of individual fish species sampled as well as environmental factors to which they are exposed in the dam.

Keywords: Length-Weight relationship; Condition Factor; Tilapia; Mormyrops; Itapaji Dam

\section{Introduction}

Fish are aquatic organisms consist of gill bearing cranium but lack limbs with digits, they are cold-blooded animals. They are of great importance for the Nigeria aquaculture industry and its production is gradually increasing. Fish like other hunting activities has been a major source of food for human race and has put an end to the unsavoury outbreak of anaemia, kwashiorkor etc. Cichlidae genera include Oreochromis, Sarotherodon and Tilapia. They add values to the life of fish farmers and commercial fishery of inland waters of most countries of the world. They are tolerance to a variety of habitats and omnivore nature of their feeding habit confers them an 
important element of fish farming which demands mode of their life and ecological requirements [1]. Mormyrops species are well distributed in swamps, lakes and rivers of most Nigerian fresh water bodies. Mormyridae include Hyperopisus, Mormyrus, Petrocephalus, Mormyrops, Marcusenius and Gnathonemus. The family Mormyridae is highly variable in shape of their head. Their common characteristics include upward pointing of pectoral fin, narrow gill openings and their eyes are small and weak and covered by a thin layer of skin. This species has always been consumed for their oily and tasty flesh according to Achionye-Nzeh, Babatunde and Aminu, Nzeh and Lawal [2-4].

FAO reported that Nigeria is one of the largest importers of fish in the developing world, importing about 600,000 metric tonnes annually [5]. To solve this short-fall in fish supply, Nigeria must be fully involved in proper aquacultural management. Scientifically sound management of fish resources relies on the basic knowledge on the biology of the species, including information on population structure, such information influences the development of the management strategies and strategies for conserving biodiversity [6]. Morphological characters such as morphometrics and meristics have been commonly used to identify stocks of fish [7,8]. Virtually, nothing is known about the morphological population structure of Cichlidae and Mormyridae species from Itapaji dam, Ekiti State, Nigeria. It is vitally important to obtain detailed knowledge on the population structure of these commercially exploited species and to apply knowledge to the management of the fisheries in the dam. This research work was therefore designed to compare the length-weight relationship and condition factor of Oreochromis niloticus, Tilapia zillii and Mormyrops anguiloides collected from Itapaji Dam, Ekiti State, Nigeria.

\section{Materials and Methods}

\section{The Study Area}

The samples were collected from Itapaji dam. The dam was constructed in 1975 for the supply of water for domestic use and production of fish for Ikole Local Government Area of Ekiti State and the environs. It is entirely within the tropics. It is located between latitude $7^{0} 53^{1} \mathrm{~N}$ and longitude $5^{0} .5^{13} 30^{11} \mathrm{E}$ of the Equator. The dam has the capacity of $5,175 \mathrm{~m}^{3} /$ day. The surface area is $115.2 \mathrm{Km}$. It's length is $400 \mathrm{~m}$ and the height is $24 \mathrm{~m}$. Its neighbours are Kwara State to the North, Kogi State to the North East, Ekiti East to the East, Gboyin Local
Government in the South and Oye Local Government in the West.

\section{Sample Collections and Identificaton}

Tilapia species (Oreochromis niloticus and Tilapia zillii) and Mormyrops species. (Mormyrops anguiloides) were collected directly from the local fish farmers. The fish were collected by set and catch net usually set overnight. The samples collected were transported to the laboratory immediately for the experiment. The $O$. niloticus, $T$. zillii and $M$. anguiloides were identified using the standard key by Olaosebikan and Raji (1998)[9].

\section{Experimental Procedure}

The fish samples bought directly from the Fishermen were transported immediately to the Post graduate laboratory of Zoology and Environmental Biology Department, Ekiti State University, Ado- Ekiti for the practicals. The fish samples were sorted into different samples and sexes and labelled properly.

\section{Data Collection}

The data on growth pattern of the species were collected through length - weight relationship by using the equation below,

$\mathrm{W}=\mathrm{aL}^{\mathrm{b}}$

Where $\mathrm{W}=$ weight of fish in grammes (g)

$\mathrm{L}=$ Total length of fish in Centimeters $(\mathrm{cm})$

$\mathrm{a}=$ intercept of the regression

$\mathrm{b}=$ Regression coefficient (slope) (Pauly, 1983) [10].

The "a" and " $b$ " values were obtained from the linear regression of the logarithm of length and weight of fish. When $b$ is equal to three (3), isomeric pattern of growth occurs but when $b$ is not equal to 3 , allometric pattern of growth occurs which may be positive if greater than 3 or negative if less than 3 . The correlation coefficient $\left(r^{2}\right)$ that shows the degree of association between the length and the weight was computed from linear regression analysis. $R=r^{2}$

The mean weight and length of the experimental fish were used to estimate condition factor using equation below:

$$
\mathrm{K}=\frac{100 \mathrm{~W}}{\mathrm{~L}^{3}}
$$

Where K-The Condition Factor

$\mathrm{W}=$ Weight in grams $(\mathrm{g})$

$\mathrm{L}=$ Total length of fish in centimeters $(\mathrm{cm})$ 


\section{Journal of Ecology \& Natural Resources}

\section{Results}

A total number of one hundred and fifty (150) Tilapia species consisted of one hundred and thirteen of Tilapia zillii (65 females and 48males) and twenty-four of Oreochromis niloticus (11 females and 13 males) and Mormyrops anguiloides (11 females and 2 males) were collected for this work.

Table 1 shows the ranges and mean values of the total length and body weight of famales and males of the three species of fish collected from Itapaji water reservoir, Ekiti State Nigeria. Among the males, Mormyrops anguiloides had highest mean length with $30.05 \mathrm{~cm}$ while the T. zillii, and $O$. niloticus had 16.59 and 16.68 respectively. The results on length among females followed the same format of the results on males. Both males and females of $M$. anguiloides outweighed others. The males had the mean weight of $172.0 \mathrm{~g}$ while the female had $145.12 \mathrm{~g}$. The males and females of 0 . niloticus followed with 84.7 and $85.11 \mathrm{~g}$ respectively.

\begin{tabular}{|c|c|}
\hline Fish species & $\begin{array}{l}\text { Total Length Body Weight } \\
\text { Sex Range Mean Range Mean }\end{array}$ \\
\hline Tilapia zillii & $\begin{array}{c}\text { Female 14.1-19.3 } 16.5439 .5-108.0 \\
77.81 \\
\text { Male 14.0-19.1 } 16.5943 .4-97.267 .47\end{array}$ \\
\hline $\begin{array}{l}\text { Oreochromis } \\
\text { niloticus }\end{array}$ & $\begin{array}{c}\text { Female } 15.5-18.116 .6461 .9-98.5 \\
85.11 \\
\text { Male } 14.0-17.816 .68 \text { 66.6-105.0 } 84.70\end{array}$ \\
\hline $\begin{array}{l}\text { Mormyrops } \\
\text { anguiloides }\end{array}$ & $\begin{array}{c}\text { Female } 24.4-39.527 .48 \text { 97.7-182.3 } \\
145.12 \\
\text { Male 28.0-32.1 } 30.05151 .9-193.4 \\
172.00 \\
\end{array}$ \\
\hline
\end{tabular}

Table 1: The ranges and mean values of the total length and body weight of the three fish species collected from Itapaji Dam, Ekiti State, Nigeria.

Table2 shows the condition factor and length-weight relationship of the males and females of the three species of fish sampled from Itapaji dam. The mean condition factor ranged from 0.75 in the females of $M$. anguiloides to 1.75 in the females of $T$. zillii. The length- weight relationship of the females and males shows that the ' $b$ ' value ranged from -1.16 in the males of 0 . niloticus to 10.12 in the males of $M$. anguiloides. The correlation coefficient " $r$ " ranged from 0.09 in the males of 0 . niloticus to 0.64 in the females of $M$. anguiloides.

\begin{tabular}{|c|c|}
\hline Fish species & $\begin{array}{c}\text { No K-factor Regression Regression } \\
\text { equation coefficient } \\
\text { Sex sampled a b } \mathbf{r}^{2} r\end{array}$ \\
\hline Tilapia zillii & $\begin{array}{c}\text { Female } 651.7580 .100 .090 .0160 .13 \\
\text { Male } 481.6337 .361 .810 .0160 .13\end{array}$ \\
\hline $\begin{array}{l}\text { Oreochromis } \\
\text { niloticus }\end{array}$ & $\begin{array}{l}\text { Female } 112.2560 .681 .460 .0210 .15 \\
\text { Male } 132.19104 .07-1.160 .0070 .09\end{array}$ \\
\hline $\begin{array}{l}\text { Mormyrops } \\
\text { anguiloides }\end{array}$ & $\begin{array}{c}\text { Female } 110.75-80.248 .200 .4080 .64 \\
\text { Male } 021.27-131.5110 .1211\end{array}$ \\
\hline
\end{tabular}

Table 2: Length-Weight relationship and condition factor of the three species collected from Itapaji Dam, Ekiti State, Nigeria.

\section{Discussion}

Among the three species of fish sampled for this work, Mormyrops anguiloides had the least sample size. The possible reason for the low number of the species may be due to over exploitation by the local fish farmers thereby makes the species a threatened one. The results further showed that the Tilapia zillii was a dominant species in the reservoir which was followed closely by $O$. niloticus during the collection periods.

The result of length- weight regression analysis in this work showed that both the males and females fish exhibited allometric growth. The values of "b" showed that both males and females of T. zillii and .Oniloticus exhibited negative allometric growth while the female and male of $M$. anguilodes exhibited positive allometric growth pattern. This means that T. zillii and $O$. niloticus become thinner or slender with increase in their length as it was reported by King, and Riedel, et al. while $M$. anguiloides becomes stocky or robust as its length increases [11,12]. The results obtained in this work were similar to what was documented on fishes of some Nigerian inland waterbodies. Notable among these Authors are Sangu et al. and Offem, et al. [13,14]. They reported $35.9 \%$ and $24 \%$ of their samples respectively exhibited negative allometrics. Dan-Kishiya (2013) reported that all the five fish species collected from a water supply reservoir in Abuja had negative allometric growth while Oso and Iwalaye reported three out of their four collections from Ero dam in Ekiti State, Nigeria had negative allometric $[15,16]$. The number of sample of Mormyrops species collected for this work was very low, in contrast to the result of Offem et al. in which the species was one of the dominant species collected from the flood plain river of Calabar, Nigeria[14]. The possible 


\section{Journal of Ecology \& Natural Resources}

reason for the number available may be due to over exploitation of the samples by the fish farmers.

The $\mathrm{b}$ values reported for $T$. zillii and $O$. niloticus males and females in this research work had were 1.81, 0.91 and $-1.16,1.14$ respectively. The values were similar to 1.4 and 2.3 reported on Wasai river, Kano samples by Imam et al. but in variance to the range of 4.73 to 15.59 recorded for T.zillii, Sarotherodon melanotheron, $T$. guinesis, T. mariae and O. niloticus from Badagry creek, Lagos by Akintade, et al. [17,18].

The ' $b$ ' values of females and males of $M$. anguiloides 8.20 and 10.12 showed that they exhibited positive allometry growth. The results were similar to 6.82 reported for Bathygobius soporator by Akintade et al. 18]. The reasons for differences in the fish growth patterns, may be due to availability of food, the season of the collection, poor environmental conditions, competition along the food chains.

The effective management of fishery resources requires considerable knowledge of population parameters such as length-weight relationship. The relationship is essentially important in fishery biology for it allows estimation of average weight of fish from a given length grou, assess the well-being of individuals and to determine the possible differences between separate unit stocks of the same species $[19,20]$. This relationship is also important in fisheries management for comparative growth studies [21]. The length- weight relationship provides valuable information on the habitat where the fish lives, and also in aquatic ecosystems modelling $[22,23]$.

Condition factor $(\mathrm{K})$ is described as a morphometric index needed to evaluate physiological status of fish based on the fact that those individuals of a given length which have a higher mass are in a better condition.

The relationship of length -weight can be used in the estimation of condition factor (K) of fish species. The condition factor obtained in this study ranged from 0.75 in the female $M$. anguiloides to 2.25 in the female $O$. niloticus which were varied from what some Authors reported, for example Oso and Iwalaye, reported 0.99455 to 4.3457 for four fish species from Ero dam, Ekiti State, Ajani reported range of 0.45 to 2.25 for five tropical fish of a coastal lake in Lagos Nigeria, Nwadiaro and Okorie reported the condition factor ranged from 0.49 to 1.48 in Oguta lake, Kumolu-Johnson and Ndimele reported the $\mathrm{K}$ value of the range of 0.91 to 8.46 for twenty-one fish species from Ologe lagoon, Lagos, while Abowei and Hart also reported $\mathrm{K}$ value of 1.10 for Cyloglossus senegalensis in Nikoro river. Ajani and Wale reported that "K" value less than 1 implied that the fish are not in good condition within their habitat while values greater than 1 implied that the fish are in good condition of physiological state within their habitat [24-28]. The " $K$ " values obtained in this study were greater than 1except in the M. anguiloides on which 0.75 was reported. Based on our findings, it could be said that all the fish samples are in good condition of well-being except the female of $M$. anguiloides in Itapaji dam, Nigeria. It was observed that the ' $\mathrm{K}$ '-values obtained in this work were lower than the range of 2.9 to 4.8 recommended as suitable for matured freshwater fish by Bagenal and Tesch [29]. The variation in values may be attributed to variations in variations in weight and stage of maturity. Other factors which might have contributed to the variations may include stress, season, availability of feeds, mutagens from human interference, and other water quality parameters.

\section{Conclusion}

The results obtained on the $T$. zillii and $O$, niloticus showed that they exhibited negative allometric growth while the $M$. anguiloides exhibited positive allometric growth. Also, the $\mathrm{K}$ values obtained revealed that the fish samples were in good condition of well-being except the females of M. anguiloides. Results also showed that the population of $M$, anguiloides is being threatened. Various factors may have contributed to variations recorded among the fish species hence; there may be need for proper examination of the water quality parameters and other factors affecting the Itapaji dam to establish the suitability of the reservoir for fish breeding.

\section{References}

1. Omoniyi IT, Agbon AO (2008) Morphometric variations in Sarotherodon melanotheron (Pisces: Cichlidae) from Brackish and freshwater habitats in South-western Nigeria. West Africa J Applied Eco 12: 01-05.

2. Achionye-Nzeh GC (1996) Morphometrics of Gnathonemus cyprinoides, Gnathonemus senegalensis and Ganthonemus pictus (Pisces:Mormyridae). Nigerian J Pure and Applied Sciences 11: 405-408.

3. Babatunde DO, Aminu R (2004) Field guide to Nigerian fresh water fishes. $2^{\text {nd }}($ Edn.) pp: 61.

4. Nzeh CG, Lawal A (2012) Condition factor, Gonadosomatic index and sex ratio of the family 


\section{Journal of Ecology \& Natural Resources}

Mormyridae from a small lake in Ilorin Nigeria. World Journal of Zoology 7(2): 102-105.

5. Food and Agriculture Organisation (FAO) (2003) Opportunities for Aquaculture Development in Nigeria. FAO Aquaculture Newsletter 17: 28.

6. Turan C, Yalcin S, Turan F, Okur E, Akyurt I (2005) Morphometric comparisons of African Catfish, Clarias gariepinus population, in Turkey. Folia Zoological 54(1-2): 165-172.

7. Teugels GG (1982) Preliminary results of a morphological study of five African species of the subgenus Clarias (Clarias) (Pisces: Clariidae). J Natural History 16(3): 439-464.

8. Turan C (2004) Stock identification of Mediterraneon Horse Mackerel (Trachurus mediterraneus) using Morphometric and meristic characters. ICES. J Marine Sciences 61(5): 774-781.

9. Olaosebikan BD, Raji A (1998) Field guide to Nigeria freshwater fishes. Decency Printers and Stationary Ltd., Ilorin, Nigeria, pp: 105.

10. Pauly D (1983) Some simple methods for the assessment of tropical fish stock. FAO fish Technical paper 234: 52 .

11. King RP (1996) Length-Weight relationship of Nigerian freshwater fishes Naga ICLARM Quarterly 19(3): 49-52.

12. Riedel R. Caskey LM, Hurlbert SH (2007) LengthWeight relationship and growth rates of dominant fishes of the Salton Sea: implications for predation by fish- eating birds. Lakes and Reservoir Management 23(5): 528-535.

13. Sangu L, Akamca E, Akarm M (2007) Weight-length relationship for 39fish species from the NorthEastern Mediterraneam Coast of Turkey. Turkish Journal of Fisheries and Aquatic Sciences 7: 37-40.

14. Offem OB, Akegbejo SY, Omoniyi IT (2009) Lengthweight relationship, condition factor and sex ratio of forty-six important fishes in a tropical flood river. J Fisheries Hydrobiology 4(2): 65-72.

15. Dan-Kishiya AS (2013) Length- Weight relationship and condition factor of five fish species from a tropical water supply reservoir in Abuja, Nigeria.
American Journal of Research Communication 1(9): 175-185.

16. Oso JA, Iwalaye AO (2016) Growth pattern and condition factor $(\mathrm{K})$ of four dominant fish species in Ero dam in Ekiti State. British J Applied Research 1(02): 8-10.

17. Imam TS, Bala U, Balarabe ML, Oyeyi TI (2010) Length -Weight relationship and condition factor of four fish species from Wasai Reservoir in Kano, Nigeria. African J General Agriculture 6(3): 125-130.

18. Akintade AO, Edwin CO, Simon EA (2016) LengthWeight relationship, condition factor and sex ratio of fish fauna in Badagry Creek, Lagos Nigeria. International J Marine Sciences 6(24): 1-8.

19. Beyer JE (1987) On length-weight relationships part1: Computing the mean weight of the fish of a given length class. Fishbyte 5(1): 11-13.

20. King $M$ (2007) Fisheries Biology Assessment and Management. $2^{\text {nd }} \quad$ (Edn.), Blackwell Scientific Publications, Oxford, pp: 189-192.

21. Moutopoulos DK, Stergiou KI (2002) Length- weight and Length -weight relationships of the fish species from Aegean Sea (Greece). J Applied Ichthyology 18(3): 200-203.

22. Pauly D (1993) Fishbyte section, editorial Naga ICLARM Q 16: 26.

23. Kulbicki M, Guillemot N, Amand M (2005) A general approach to length -weight relationships for new Caledonian Lagoon fishes Cybium 29: 235-252.

24. Ajani GE (2013) Prelimnary studies of the condition factors in five tropical fish species of a Coastal State, Lagos Nigeria Researcher 5(6): 1-5.

25. Nwadiaro CS, Okorie PU (1995) Biometric characteristics and Length-weight relationships and Condition factors in Chrychthys filamentosus. Pisces: Bagridae from Oguta lake. Nigeria Biological Africa 2: 48-56.

26. Kumolu-Johnson CA, Ndimele PE (2010) LengthWeight relationships of nine fish species from Ologe lagoon, Lagos, Nigeria. African Journal of Biotechnology 10(2): 241-243.

27. Abowei JFN, Hart AI (2009) Some morphometric parameters of 10 finfish species from the lower Nun 


\section{Journal of Ecology \& Natural Resources}

river, Niger-Delta, Nigeria. Research J Biological Sciences 4(3): 282-288.

28. Wade JW (1992) The relationship between temperature, food intake and growth of Brown trout Salmo trutta (L) fed natural and artificial pelted diet in earth pond. Journal of Aquacultural Sciences 7: 5971.
29. Bagenal TB, Tesch FW (1978) Age and growth in methods for assessing of fish production in freshwaters. In: Bagenal TB (Ed), $3^{\text {rd }}$ (Edn.), No 3 Blackwell Scientific Publication. 